\title{
Applying a Balanced Scorecard Approach in Egyptian Travel Agencies: Opportunities and Obstacles
}

Fakhory Shohdy Ayoub ${ }^{1} \quad$ Sabreen Gaber Abd El- Jalil ${ }^{1}$ Wafaa Ahmed Nour El-Dien Elias ${ }^{2}$

${ }^{1}$ Faculty of Tourism and Hotels- Luxor University, ${ }^{2}$ Faculty of Tourism and Hotels- Minia University

\begin{abstract}
It is widely acknowledged that Egyptian travel agencies face more competition and need to apply the Balanced Scorecard (BSC) as effective performance measurement systems in order to be competitive and to remain in existence. The purpose of this study is to determine the availability of the basic ingredients for BSC application and its opportunities and obstacles. 300 questionnaire forms targeted managers of head offices and their branches. The Statistical Package for Social Sciences (SPSS) version 26 was used to analyze collected data. The result of the study showed that Egyptian travel agencies could apply the BSC. The obstacles do not significantly affect the application of BSC. There are significant differences between the head offices and branches regarding the availability of the BSC basic ingredients and its perspectives application. The study recommends that travel agencies need to support intensives and training programs to their staff to awareness them by the BSC implementation and its use to monitor the performance.
\end{abstract}

Keywords: Balanced Scorecard, Egyptian Travel Agencies Obstacles, Opportunities, Performance.

\section{Introduction}

Kala and Bagri (2014) indicated that organizations need to achieve a balance between financial and non-financial measures. Furthermore, the nonfinancial measures play the main role in their future performance improvements. Cooper and Hall (2008) explained that the BSC allows organizational managers to look at their business from many different perspectives based on the vision and strategic objectives of the particular organization. Egyptian travel agencies draw their attention to explore the opportunities for BSC implementation and the obstacles faced its application. According to Libby, Salterio, and Webb (2004), the BSC is a comprehensive set of performance measures that focus on a company's current position and future visions. The key aim of the BSC is to provide a more balanced view of a firm's performance based on financial, customer, internal, and learning and growth perspectives.

Mooraj, Oyon, and Hostettler (1999, p. 481) defined BSC as "a tool which adds value by providing both relevant and balanced information in a concise way for managers, creating an environment which is conducive to learning organizations and eliminating the need for managers to 'choose' which type of control system to use at any given time". Niven (2006) defined the BSC as the tool that answers the complex challenges. These challenges include the development of performance measurement systems and the existence of a system that balances the historical accuracy of financial outcomes with the drivers of future performance.

The BSC helps modern organizations to examine the rise of intangible assets and their impact on the ability to measure corporate performance accurately(Agyeman, Bonn, \& Osei, 2017). Agbanu, Nayrko, Agbemava, Sedzro, and Selase (2016) revealed that there are varied approaches to designing and implementing performance measurement systems. However, the measures of the BSC approach are more to provide direct information on an organization's performance. The current research aims to identify the availability of the basic integrates as opportunities for implementing the BSC in the Egyptian travel agencies. It determines the differences between the head offices and their branches in Cairo and Luxor regarding the availability of the BSC basic 
ingredients and its perspectives application. Meanwhile, it explores the various obstacles and their effect on the application of BSC.

\section{Literature review}

Uses of the BSC

Edwards and Service (2008) mentioned the reasons led to companies' use of the BSC such as:

- It supports the communication of strategy throughout the company.

- It leads to align the goals with strategy.

- This card links strategic objectives to long-term targets and annual budgets.

- It helps to identify strategic initiatives.

- It provides regular reports and information about the performance for strategic level management to monitor what is being achieved and to take suitable action when necessary.

\section{Components of the Balanced Scorecard Framework}

Fawy, Mohammad, and Dawood (2018) revealed that the BSC conceptual framework usually consists of two parts. The first part includes the vision, mission, and four perspectives, while another part reflects that the BSC perspectives are linked together in a cause-and-effect relationship. Each perspective includes objectives, measures, targets, and initiatives (see fig. 1).

Fig. 1: Components of the Balanced Scorecard

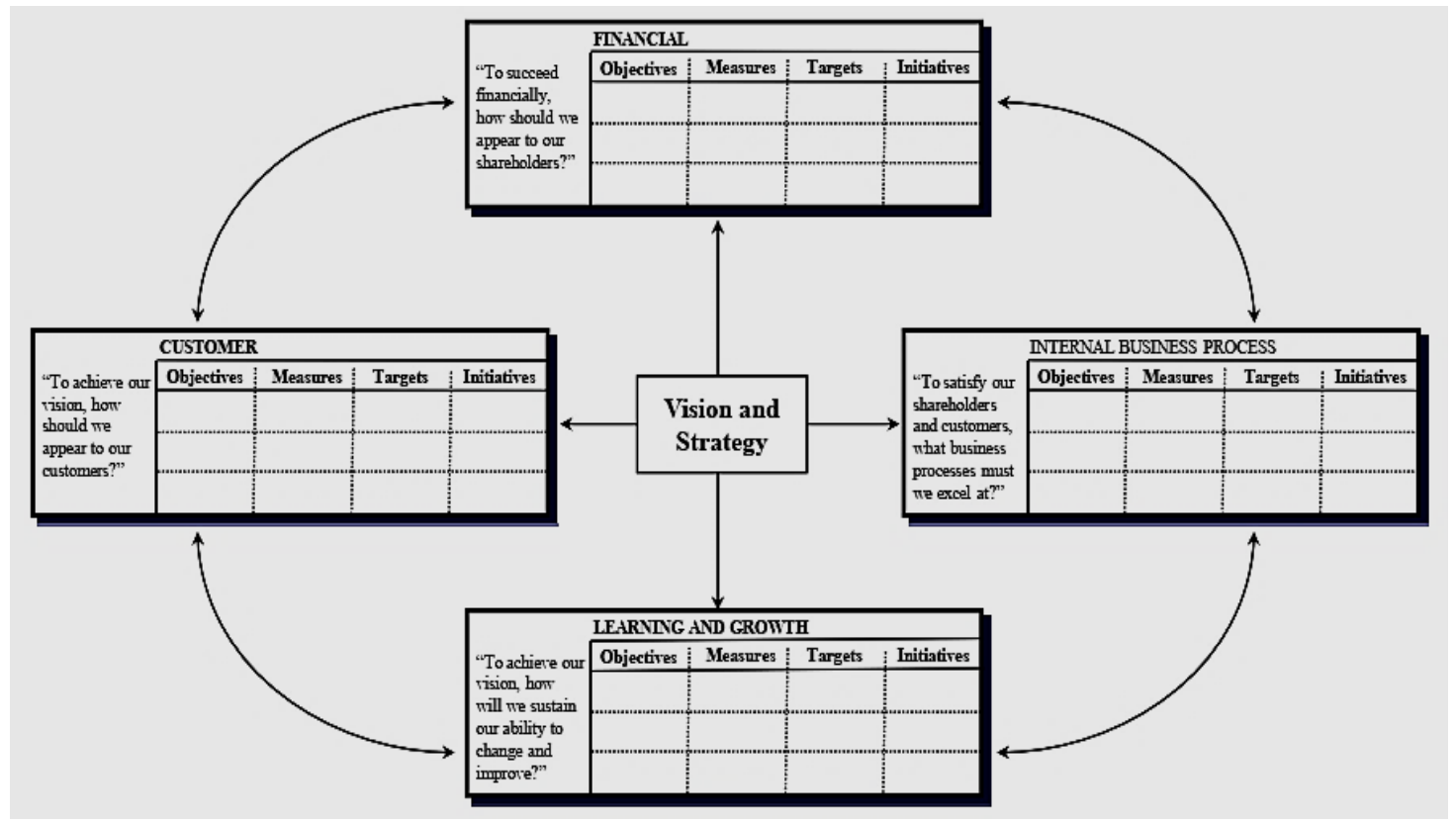

Source: (Kaplan, 2009, p. 4)

\section{Vision and Mission}

Ireland, Hoskisson, and Hitt (2008) assured that every company should have a vision and mission. There are many strategic and tactical decisions that are faced by companies in the tourism and hospitality industries. The strategic decisions should be taken according to the company's mission and vision because they are long-term and complex in nature (Enz, Canina, \& Lomanno, 2010). Schalm (2008) assured that the mission and vision usually focus on some concepts that include service quality, the clients and stakeholders served innovation and leadership, and partnerships with the community. Each of these items appears as a dimension or indicators during the BSC implementation (see figure2). 
Fig2: The Framework of the Balanced Scorecard Perspectives.

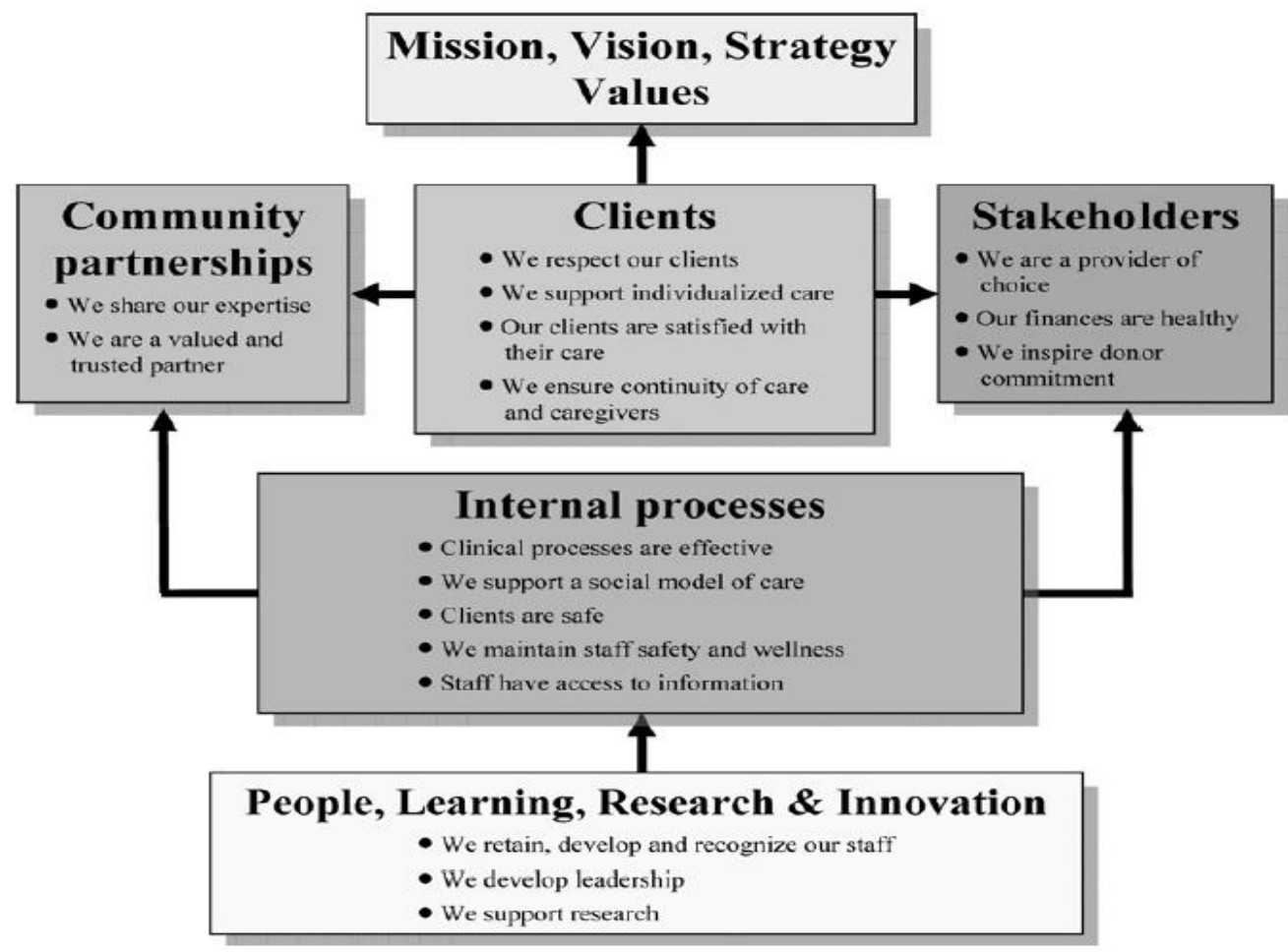

Source: (Schalm, 2008, p. 10)

The first step of BSC implementation is the translation of vision through the senior management team who translate the firm vision into strategic objectives (Hsu \& Liu, 2010). Although a mission statement clarifies the essential purpose of the company or why it exists, it reflects the motivations of employees for participating in the company's business. The mission determines the particular activities or initiatives that are in alignment with the company's purpose easily (Niven, 2014).

\section{The Four Perspectives of the BSC}

Many kinds of literature identified the internal process as an excellence for the future. Services quality and facility of travel agencies are the best two factors in this category in the tourism industry (Kerai \& Saleh, 2017). Borza and Bordean (2006) mentioned that the internal measures of the BSC should aim at quality, employee skills, and productivity. The learning and innovation perspective helps managers to measure the internal performance of the business by identifying the following: employee turnover, revenue by segment, complaint responses, etc. Companies can shape their strategies toward achieving a competitive advantage and value creation through learning processes (Curtis, Hanias, \& Antoniades, 2011). Fretheim (2013) illustrated that companies can create value through three internal business processes. The three processes are innovation process, operation process, and post-sale service. This perspective is focused on creating value and innovation.

Sahin (2014) referred to satisfaction as a happy feeling when you have achieved what you wanted. Customer satisfaction plays a vital role in achieving the goals and objectives of companies, so it should be one of their most significant objectives. The main priority of successful companies is to meet their customers' demands around the world. Four main concerns of customers regarding the product or service are time, quality, performance \& service, and cost. 
Hence, the companies need to adapt their targets in accordance with these four elements (Giannopoulos, Holt, Khansalar, \& Cleanthous, 2013).

Financial perspective usually answers the main question: how does an organization look to its shareholders? Financial measures clarify the degree of improvement in the final results through strategy execution (Mulat, 2015). Al-Najjar and Kalaf (2012) revealed that the company's economic outcomes are showed by financial measures after companies made actions. According to Van Staden (2009), financial measures include operating income; return on assets; return on equity; revenue growth; sales growth and cash flow; and economic value-added. Kang, Chiang, Huangthanapan, and Downing (2015) and Garg (2013) considered social responsibility as the duty of an individual or organization to achieve a balance between achieving the financial gains and the preservation of society. Recently, there is a great need to measure the social dimension which is represented in making a social role of the Egyptian travel agencies.

\section{Objectives, Measures, Target, and Initiatives}

A primary purpose of the BSC design is to help any company effectively execute its strategy. BSC is not one single thing, but it is composed of four integrated elements: objectives, measures, targets, and strategic initiatives. These four elements unite to create a powerful unified whole (Niven, 2014). Companies develop their objectives, measures, targets, and initiatives for each one of the BSC perspectives(Amado, Santos, \& Marques, 2012).

\section{Limitations of the BSC}

There are many challenges and limitations facing the implementation of BSC as follows (Fawy et al., 2018; Kaplan \& Norton, 2004; Lipe \& Salterio, 2000; Phillips \& Louvieris, 2005):

- There are multiple endeavors to implement the BSC such as the gathering of scorecardrelated data, the formatting of scorecard reports, and the distribution of scorecard information.

- Managers disregarded unique measures for specific units and used only the common measure for determining performance in the evaluation. The unique variables need to be weighted in using the BSC approach.

- One of these barriers is a failure to establish linkages between scorecard components and a failure to save the support of employees for the BSC evaluation system.

- The top management support is one of the most important factors for the BSC system implementation. Furthermore, the application process needs to communicate the required information about the BSC to all employees.

\section{Methodolagy}

The questionnaire was used to gather the primary data and was distributed to managers and department managers in travel agencies and their branches in Cairo and Luxor cities. A sample of 300 head offices and branches was selected from Cairo and Luxor. Questionnaires were collected and distributed in seven months. The questionnaire was divided into five parts that include personal information of managers and officials, the need for a BSC system, availability of the basic ingredients, obstacles that can face the BSC application, and the extent of application of the BSC four perspectives. Respondents' answers were indicated on the five-point Likert scale where '5' represents 'strongly agree' and ' 1 ' represents 'strongly disagree'.

The data results were statistically analyzed through SPSS program version 26. Adequate statistical analyses such as frequency, mean, standard deviation, and T-Test were used to identify the differences between head offices and their branches regarding the BSC basic ingredients and its perspectives application. Three referees have attributed the emphasis on the questionnaire 
content validity and the issues surrounding its items clarification. It leads to avoid any misunderstanding and to assure the questions linkage with the objectives of the study. A Cronbach's alpha (0.92) was found from the pilot test of the portion of this instrument used to know BSC perspectives application in the head office and branches. The results indicate that the questionnaire was reliable with a high degree of internal consistency. According to these positive results, no modifications were made to the instrument.

\section{Results and discussion}

\section{Summary of Respondents' Personal Information}

The findings reflect the respondents' experience and the importance of their Job positions because more than $73 \%(n=221)$ of them have a great work experience for more than 11 years. Moreover, most of the respondents (more than 58\%) are a manager for head offices and branches as well as $73 \%(n=219)$ of the sample are worked in the most important departments such as tourism, aviation, and marketing. The results declare that the head offices represent $72.7 \%(\mathrm{n}=$ 218), while the branches represent $27.3 \%(n=82) .79 .7 \%$ of the travel agencies selected are located in Cairo and $20.3 \%$ of the sample is located in Luxor. This sample was chosen for its ability to uncover the opportunities and obstacles that may face the application of the card and their differences between the head offices and branches.

\section{The Opportunities for the BSC Application in Egyptian Travel Agencies}

Objective one aims to explore the availability of the basic ingredients as opportunities for implementing the BSC in the Egyptian travel agencies. The next table (1) included a deeper understanding of the availability of the BSC opportunities and their application.

Table 1: The availability of the BSC basic ingredients in the Egyptian travel agencies

\begin{tabular}{|c|l|c|c|c|c|}
\hline \multirow{2}{*}{ No } & \multicolumn{1}{|c|}{ Items } & \multicolumn{1}{c|}{ Frequency } & \multicolumn{2}{c|}{ Percent } \\
\cline { 3 - 5 } & & \multicolumn{1}{|c|}{ Yes } & No & Yes & No \\
\hline 1 & The BSC is used to measure performance inside travel agencies. & 0 & 300 & 0.0 & 100.0 \\
\hline 2 & Travel agency has a clear strategy and plan for all stakeholders. & 267 & 33 & 89.0 & 11.0 \\
\hline 3 & Travel agency has human resources capable of achieving its strategy. & 278 & 22 & 92.7 & 7.3 \\
\hline 4 & There is a clear, confident, and stated vision for all its employees. & 282 & 18 & 94.0 & 6.0 \\
\hline 5 & There is a confident and stated mission for all its employees & 285 & 15 & 95.0 & 5.0 \\
\hline 6 & $\begin{array}{l}\text { Travel agency declares and communicates objectives to all its } \\
\text { employees. }\end{array}$ & 281 & 19 & 93.7 & 6.3 \\
\hline 7 & $\begin{array}{l}\text { The policies followed by it are clear for all employees and help in } \\
\text { implementing the objectives. }\end{array}$ & 283 & 17 & 94.3 & 5.7 \\
\hline 8 & $\begin{array}{l}\text { The management relies on financial and non-financial indicators in } \\
\text { assessing its performance. }\end{array}$ & 277 & 23 & 92.3 & 7.7 \\
\hline 9 & $\begin{array}{l}\text { Travel agency assesses its performance by linking the vision with the } \\
\text { objectives. }\end{array}$ & 255 & 45 & 85.0 & 15.0 \\
\hline 10 & $\begin{array}{l}\text { Travel agency has a good accounting system in addition to an } \\
\text { accountant that is capable of achieving its vision effectively. }\end{array}$ & 283 & 17 & 94.3 & 5.7 \\
\hline 11 & Internal processes are evaluated to achieve its main objectives. & 265 & 35 & 88.3 & 11.7 \\
\hline 12 & $\begin{array}{l}\text { A highly efficient and professional internal management system is } \\
\text { available. }\end{array}$ & 282 & 18 & 94.0 & 6.0 \\
\hline 13 & $\begin{array}{l}\text { Internal communications between different management levels are } \\
\text { effective. }\end{array}$ & 293 & 7 & 97.7 & 2.3 \\
\hline 14 & The satisfaction of tourists towards the services provided is assessed. & 293 & 7 & 97.7 & 2.3 \\
\hline 15 & Travel agency relies on training and innovation to survive. & 263 & 37 & 87.7 & 12.3 \\
\hline
\end{tabular}


All of the respondents indicated that they did not use BSC to measure performance inside their travel agencies. However, the majority of administrators (more than 90\%) indicated that they have vision, mission, and policies that are clear and stated vision for all its employees. The respondent administrators strongly agreed that financial indicators in their agencies are necessary but not sufficient for performance assessment. It is noteworthy to mention that travel agencies have human resources capable of achieving their strategy, good accounting systems, highly efficient and professional internal management systems, and efficient internal communications between different management levels. The head offices and their branches assign more importance to the satisfaction of tourists towards their services provided (90\%), evaluation of internal processes $(88.3 \%)$, and finally the training and innovation $(87.7 \%)$ that helps in implementing the BSC in their organization.

As expected, although many respondents referred to using all the dimensions of BSC in performance measurement, they are not aware of the concept of BSC and its four perspectives in a formal manner. Results shown in table 1 indicated that they are applying all four perspectives of BSC unknowingly. These results agree with the previously stated in the literature review (Nurcahyo, Wibowo, \& Putra, 2015; Rasoolimanesh, Jaafar, Badarulzaman, \& Ramayah, 2015) which clarified that a clear and announced vision and mission are the basic requirements for implementing BSC in the large and small organizations. These results are consistent with Giannopoulos et al. (2013) who clarified that companies don't focus only on financial indicators to direct their strategic vision and to determine the satisfaction of customers and employees. In light of the above discussion, the basic Ingredients for applying the BSC are available in the Egyptian travel agencies. Hence, the Egyptian travel agencies have the ability to apply the BSC.

\section{Obstacles faced the BSC Application in the Egyptian Travel Agencies}

With regard to the discovery of obstacles faced the BSC application, the table (2) shows that the respondents regarded the lack of information on BSC, its application, and the lack of awareness of its importance in improving performance as the principal obstacles that face implementing the BSC. The means of responses are 4.04 and 4.03 with the standard deviations $(.781, .953)$ that clarify the strength of the results. They reported that resistance of employees to the new evaluation methods and lack of qualified competencies to understand the use of BSC (mean response $3.15 ; 3.14$ and std. $=1.170 ; 1.120$ ) can be encountered during implementation. Furthermore, they indicated the time required to apply the BSC (mean response 3.00) is not hugely unobstructed. The support from management is critical to implementing the BSC successfully, so the responses of managers were consistent with this principle.

Table 2: Descriptive statistics of obstacles faced the BSC application for evaluating the performance of Egyptian travel agencies

\begin{tabular}{|l|l|l|l|l|}
\hline No & \multicolumn{1}{|c|}{ Items } & Mean & Std. Deviation & Rank \\
\hline 1. & Lack of information on BSC and its application. & 4.04 & .781 & 1 \\
\hline 2. & $\begin{array}{l}\text { The management does not support the BSC application as a tool } \\
\text { for performance evaluation. }\end{array}$ & 2.98 & 1.145 & 7 \\
\hline 3. & It needs a long time to apply the BSC skillfully. & 3.00 & 1.164 & 5 \\
\hline 4. & $\begin{array}{l}\text { Its employees resist the change of current measurement and } \\
\text { evaluation methods. }\end{array}$ & 3.15 & 1.170 & 3 \\
\hline 5. & $\begin{array}{l}\text { BSC model design is expensive. } \\
\text { There is a lack of qualified competencies to understand the use of } \\
\text { BSC. }\end{array}$ & 3.14 & 1.120 & 7 \\
\hline 7. & $\begin{array}{l}\text { There is a lack of awareness of the importance of a BSC in } \\
\text { improving the performance. }\end{array}$ & 4.03 & .953 & 2 \\
\hline \multicolumn{1}{|l|}{ Valid N (Listwise) } & 3.30 & 0.557 & 7 \\
\hline
\end{tabular}


According to the opinions of respondents, the expensive of the BSC model design is not an obstacle (mean response 2.76, std. $=1.147$ ), because they agreed that the benefits of the BSC would outweigh its costs if it were implemented successfully (mean response 2.76, std.=1.147). These results are in agreement with the studies by Giannopoulos et al. (2013), Koumpouros (2013), and Kasasbeh (2018) who stated that the reasons for not applying BSC are a lack of awareness of BSC application and its role in improving performance. The results agree with the studies of Al-Zwyalif (2012), and Cheng, Dainty, and Moore (2007). They indicated that companies would need to involve their employees and to support of management at all levels of the BSC application. According to the above results, there are various barriers facing the BSC application in Egyptian travel agencies.

\section{Evaluating the BSC Perspectives implentation in the Egyptian travel agencies}

The results reveal the evaluation of the five BSC perspectives to identify the most and least implemented in the Egyptian travel agencies. There is no more difference in the importance assigned to various perspectives across the classification of the participants except the social responsibility perspective (mean $=3.39$ ) which has been given less importance in the most head offices and branches. The financial perspective scores the highest mean (4.14) in the performance measurement across travel agencies in Cairo and Luxor. Participants clarified that travel agencies have the highest mean for customers' perspective and internal process perspective (mean $=3.99$, 3.87). Surprisingly, the learning and innovation perspective (mean $=3.69$ ) could not find its due place during the performance measurement processes.

T-test was used to identify the differences between types of travel agencies with respect to the BSC basic ingredients and its perspectives application. Data presented in the table (3) clearly indicates that there are significant differences in the availability of the BSC basic ingredients and its perspectives application between the head offices and branches in Cairo and Luxor ( $\mathrm{p}$-value = $0.005,0.007,0.037,0.007)$, except for the learning and innovation perspective and social responsibility perspective ( $\mathrm{p}$-value $=0.186,0.102$ ). The results illustrate that head offices (mean $=13.12$ ) have the basic ingredients for the BSC application more than branch (mean response = 12.51). Financial perspective, internal processes perspective, and customer perspective are applied in head offices (mean $=37.66,47.00,52.40)$ to a greater degree than in branches $($ mean $=$ $36.16,45.06,50.66$ ). According to the above results, the BSC can be applied in the head offices more than their branches, because the the head offices own the basic ingredients for the BSC application and implement the BSC perspective more than the branches.

Table 3: Independent samples T-test for the differences between types of travel agencies with respect to the BSC basic ingredients and its perspectives application

\begin{tabular}{|c|c|c|c|c|c|c|c|c|}
\hline No & BSC Perspectives & $\begin{array}{c}\text { Types of } \\
\text { travel agency }\end{array}$ & $\mathrm{N}$ & Mean & $\begin{array}{c}\text { Std. } \\
\text { Deviation }\end{array}$ & $\mathrm{t}$ & df & $\begin{array}{c}\text { Sig. } \\
\text { (2-tailed) }\end{array}$ \\
\hline \multirow[t]{2}{*}{1} & \multirow{2}{*}{$\begin{array}{l}\text { Availability of the basic } \\
\text { ingredients for BSC } \\
\text { application }\end{array}$} & Head Office & 218 & 13.12 & 1.657 & \multirow[t]{2}{*}{2.846} & \multirow[t]{2}{*}{298} & \multirow[t]{2}{*}{.005} \\
\hline & & Branch & 82 & 12.51 & 1.665 & & & \\
\hline \multirow{2}{*}{2} & \multirow{2}{*}{$\begin{array}{l}\text { Obstacles that can face BSC } \\
\text { application }\end{array}$} & Head Office & 218 & 23.16 & 3.944 & \multirow[t]{2}{*}{.404} & \multirow[t]{2}{*}{298} & .686 \\
\hline & & Branch & 82 & 22.95 & 3.810 & & & n.s \\
\hline \multirow[t]{2}{*}{3} & \multirow{2}{*}{$\begin{array}{l}\text { Learning and Innovation } \\
\text { Perspective }\end{array}$} & Head Office & 218 & 37.17 & 5.221 & \multirow[t]{2}{*}{1.324} & \multirow[t]{2}{*}{298} & .186 \\
\hline & & Branch & 82 & 36.26 & 5.504 & & & n.s \\
\hline \multirow{2}{*}{4} & \multirow{2}{*}{ Internal Processes Perspective } & Head Office & 218 & 47.00 & 5.757 & \multirow[t]{2}{*}{2.699} & \multirow[t]{2}{*}{298} & \multirow[t]{2}{*}{.007} \\
\hline & & Branch & 82 & 45.06 & 4.987 & & & \\
\hline \multirow{2}{*}{5} & \multirow[t]{2}{*}{ Customer Perspective } & Head Office & 218 & 52.40 & 6.408 & \multirow[t]{2}{*}{2.092} & \multirow[t]{2}{*}{298} & \multirow[t]{2}{*}{.037} \\
\hline & & Branch & 82 & 50.66 & 6.521 & & & \\
\hline
\end{tabular}


International Journal of Heritage, Tourism and Hospitality Vol. (14), No. (1), June, 2020

\begin{tabular}{|c|c|c|c|c|c|c|c|c|}
\hline No & BSC Perspectives & $\begin{array}{c}\text { Types of } \\
\text { travel agency }\end{array}$ & $\mathrm{N}$ & Mean & $\begin{array}{c}\text { Std. } \\
\text { Deviation }\end{array}$ & $\mathrm{t}$ & df & $\begin{array}{c}\text { Sig. } \\
\text { (2-tailed) }\end{array}$ \\
\hline \multirow[t]{2}{*}{6} & \multirow[t]{2}{*}{ Financial Perspective } & Head Office & 218 & 37.66 & 3.976 & \multirow[t]{2}{*}{2.703} & \multirow[t]{2}{*}{298} & \multirow[t]{2}{*}{.007} \\
\hline & & Branch & 82 & 36.16 & 5.034 & & & \\
\hline \multirow[t]{2}{*}{7} & Social Responsibility & Head Office & 218 & 34.32 & 5.555 & \multirow[t]{2}{*}{1.640} & \multirow[t]{2}{*}{298} & .102 \\
\hline & Perspective & Branch & 82 & 33.12 & 5.878 & & & n.s \\
\hline
\end{tabular}

The table (4) examines the effect of obstacles as a control variable on the relationship between all BSC perspectives as follows:-

- Learning and innovation perspective with other perspectives $\left(\mathrm{r}=0.615^{* *}, 0.551^{* *}, 0.329^{* *}\right.$, $0.481 * *)$, which is highly significant $\mathrm{p}$. value $=(0.00)$.

- Internal processes perspective with customer perspective, financial perspective, and social responsibility perspective $\left(\mathrm{r}=0.541^{* *}, 0.331^{* *}, 0.449^{* *}\right)$, which is highly significant $\mathrm{p}$. value $=(0.00)$.

- Customer perspective with financial perspective, and social responsibility perspective $(\mathrm{r}=$ $0.572 * *, 0.528 * *)$, which is highly significant $\mathrm{p}$. value $=(0.00)$.

- financial perspective with social responsibility perspective $(\mathrm{r}=0.372 * *)$, which is highly significant $\mathrm{p}$. value $=(0.00)$.

- The results reflected that although there are some obstacles faced BSC application (see table 4), they have not a significant effect on the relationship between all BSC perspectives (p. value $=0.00$ ).

According to the previous results, the obstacles do not significantly affect the application of BSC in the Egyptian travel agencies.

Table 4: The effect of obstacles on the relationship between all BSC perspectives

\begin{tabular}{|c|c|c|c|c|c|c|c|c|}
\hline $\begin{array}{c}\text { Control } \\
\text { variables }\end{array}$ & & & $\begin{array}{c}\text { Learning \& } \\
\text { innovation } \\
\text { perspective }\end{array}$ & $\begin{array}{c}\text { Internal } \\
\text { processes } \\
\text { perspective }\end{array}$ & $\begin{array}{l}\text { Customer } \\
\text { perspective }\end{array}$ & $\begin{array}{c}\text { Financial } \\
\text { perspective }\end{array}$ & $\begin{array}{c}\text { Social } \\
\text { responsibility } \\
\text { perspective }\end{array}$ & Barriers \\
\hline \multirow[t]{15}{*}{ Barriers } & \multirow{3}{*}{$\begin{array}{l}\text { Learning \& } \\
\text { innovation } \\
\text { perspective }\end{array}$} & Correlation & 1.000 & 615 & .551 & .329 & .481 & \multirow[t]{15}{*}{0} \\
\hline & & $\begin{array}{l}\text { Significance } \\
\text { (2-tailed) }\end{array}$ & . & .000 & .000 & .000 & .000 & \\
\hline & & Df & 0 & 297 & 297 & 297 & 297 & \\
\hline & \multirow{3}{*}{$\begin{array}{l}\text { Internal } \\
\text { processes } \\
\text { perspective }\end{array}$} & Correlation & .615 & 1.000 & .541 & .331 & .449 & \\
\hline & & $\begin{array}{l}\text { Significance } \\
\text { (2-tailed) }\end{array}$ & .000 & 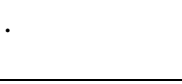 & .000 & .000 & . 000 & \\
\hline & & Df & 297 & 0 & 297 & 297 & 297 & \\
\hline & \multirow{3}{*}{$\begin{array}{l}\text { Customer } \\
\text { perspective }\end{array}$} & Correlation & .551 & .541 & 1.000 & .572 & .528 & \\
\hline & & $\begin{array}{l}\text { Significance } \\
\text { (2-tailed) }\end{array}$ & .000 & .000 & 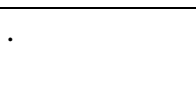 & .000 & .000 & \\
\hline & & Df & 297 & 297 & 0 & 297 & 297 & \\
\hline & \multirow{3}{*}{$\begin{array}{l}\text { Financial } \\
\text { perspective }\end{array}$} & Correlation & .329 & .331 & .572 & 1.000 & .372 & \\
\hline & & $\begin{array}{l}\text { Significance } \\
\text { (2-tailed) }\end{array}$ & .000 & .000 & .000 & & .000 & \\
\hline & & Df & 297 & 297 & 297 & 0 & 297 & \\
\hline & \multirow{3}{*}{$\begin{array}{l}\text { Social } \\
\text { responsibility } \\
\text { perspective }\end{array}$} & Correlation & .481 & . 449 & .528 & .372 & 1.000 & \\
\hline & & $\begin{array}{l}\text { Significance } \\
\text { (2-tailed) }\end{array}$ & .000 & .000 & .000 & .000 & & \\
\hline & & Df & 297 & 297 & 297 & 297 & 0 & \\
\hline
\end{tabular}

The following results of regression analysis reflect the effect of availability of the basic ingredients and obstacles faced the BSC application in the Egyptian travel agencies on the BSC 
perspectives. Availability of the BSC basic ingredients and obstacles of the BSC application can explain the variation in the BSC perspectives as follows:

- Firstly, the availability of the BSC basic ingredients and obstacles of the BSC application can explain $15.6 \%$ of the variation in the learning and innovation perspective (R Square =.156). The F-statistic $=(27.405)$ and 299 degrees of freedom are significant as well as the p-value (0.00) is less than the alpha value 0.05 .

- Secondly, it can explain $11 \%$ of the variation in the internal processes perspective. The Fstatistic (18.398), the p-value (0.00), and 299 degrees of freedom are significant.

- Thirdly, it can explain $13.5 \%$ of the variation in the customer perspective. The F-statistic (23.220) and 299 degrees of freedom are significant as well as the p-value is (0.00).

- Fourthly, it can explain $16.1 \%$ of the variation in the financial perspective. The p-value $(0$. 00), the F-statistic (28.521), and 299 degrees of freedom are significant.

- Finally, it can explain $11.6 \%$ of the variation in the social responsibility perspective. The Fstatistic (19.420) and 299 degrees of freedom are significant. The p-value is (0.00).

Table 5: Coefficients

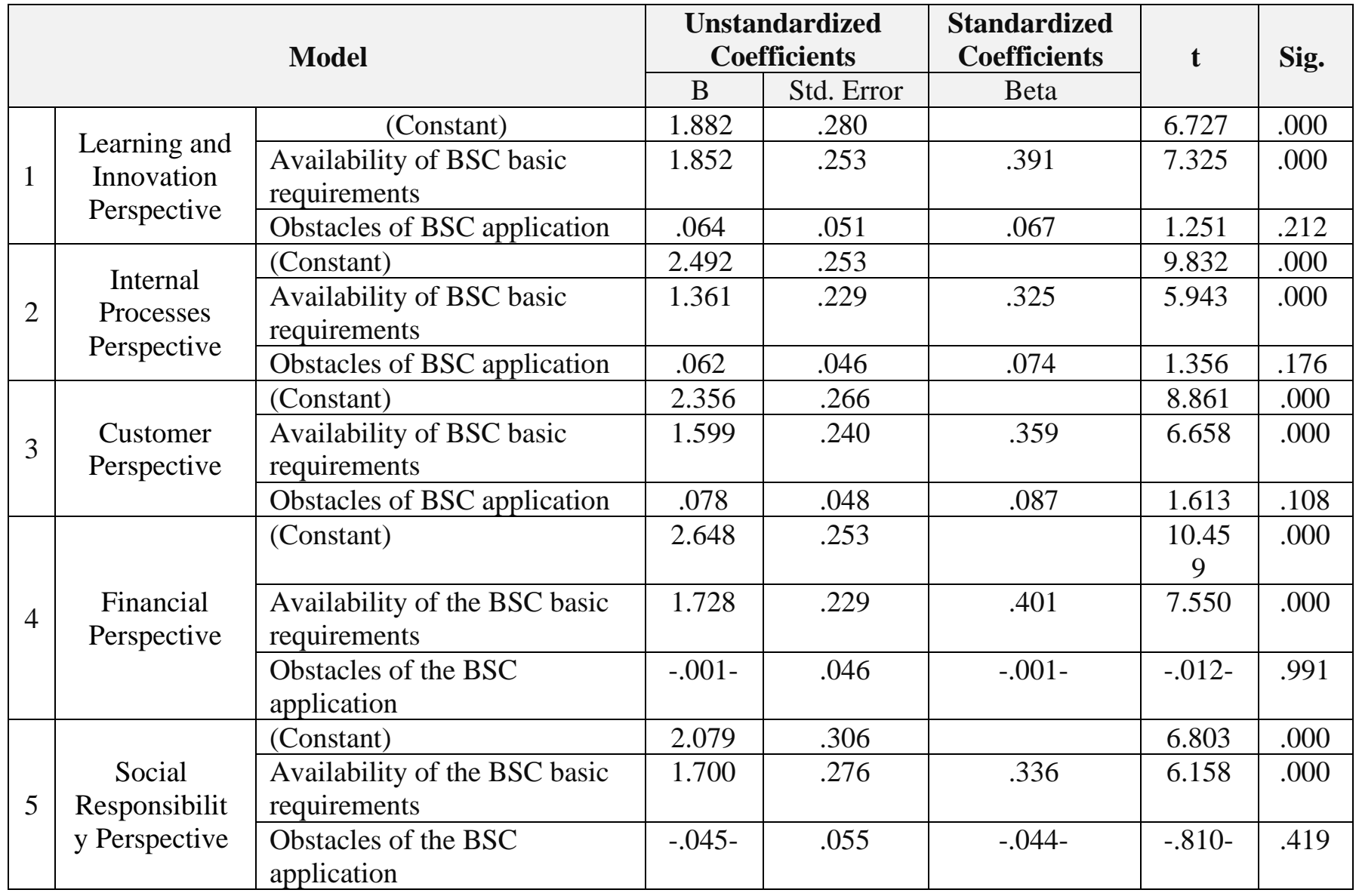

The results in the table (5) illustrated the linear regression analysis between the independent variable (Availability of the basic ingredients and Obstacles faced the BSC application) and the dependent variable (the BSC perspectives) the as follows: -

- Learning and innovation perspective: the study found that the linear regression analysis estimates the linear regression function to be $y=1.882+(1.852) \mathrm{x} 1$. This means that an increase in one unit of availability of the BSC basic ingredients results in an increase of 
(1.852) units of the learning and innovation perspective. The t-test found that there is a highly significant $(\mathrm{p}=0.00)$ between intercept and variables. According to the above results, the availability of the BSC basic ingredients (beta .391) has a higher impact on applying the learning and innovation perspective.

- Internal processes perspective: the linear regression analysis estimates the linear regression function to be $y=2.492+(1.361) \times 2$. This means that an increase in one unit of availability of the BSC basic ingredients results in an increase of (1.361) units of the internal processes perspective. There is a highly significant $(\mathrm{p}=0.00)$ between intercept and variables. The findings illustrated that the availability of the BSC basic ingredients (beta $=.325$ ) has a higher impact on applying the internal processes perspective.

- Customer perspective: the linear regression analysis estimates the linear regression function to be $y=2.356+(1.599) \times 3$. This means that an increase in one unit of availability of the BSC basic ingredients results in an increase of (1.599) units of the customer perspective. According to the t-test results, there is a highly significant $(\mathrm{p}=0.00)$ between intercept and variables. The results clarify that the availability of the BSC basic ingredients (beta =.359) has a higher impact on applying the customer perspective.

- Financial perspective: the results clarified that the linear regression analysis estimates the linear regression function to be $y=2.648+(1.728) \times 4$. This means that an increase in one unit of availability of the BSC basic ingredients results in an increase of (1.037) units of the financial perspective. The t-test found that there is a highly significant $(p=0.00)$ between intercept and variables. The findings assured that the availability of the BSC basic ingredients (beta $=.401$ ) has a higher impact on applying the financial perspective.

- Social responsibility perspective: the linear regression analysis estimates the linear regression function to be $y=2.079+(1.700) \times 5$. This means that an increase in one unit of availability of the BSC basic ingredients results in an increase of ((1.700) units of the social responsibility perspective. Moreover, there is a highly significant $(\mathrm{p}=0.00)$ between intercept and variables. The results illustrated that the availability of the BSC basic ingredients (beta $=.336$ ) has a higher impact on applying the social responsibility perspective.

These results are consistent with Valmohammadi and Servati (2011) and Quesado, Aibar Guzmán, and Lima Rodrigues (2018) who assured the importance of basic requirements for implementing BSC in the large and small organization. Moreover, Elshahat (2016) stated the effect of tangible and intangible assets " the BSC basic" on the performance measurement process in companies. The results demonstrate the importance of the availability of basic ingredients for implementing the BSC perspectives in Egyptian travel agencies.

\section{Conclusions and Recommendations}

The BSC considers an important tool for many travel agencies to align their goals with strategy. It provides regular information and reports about the performance of companies and helps managers to look at suitable procedures when necessary. The purpose of this paper was to explore the opportunities and obstacles faced the BSC application in travel agencies. 335 questionnaires were distributed to managers and department managers in travel agencies and their branches in Cairo and Luxor cities. A Cronbach's alpha was (0.92) and indicates that the questionnaire was reliable. Furthermore, frequency, mean, standard deviation, and T-Test were used. The empirical findings of this research revealed that the basic requirements of BSC application and its perspective are available in the head offices and their branches, thus the BSC 
with its perspectives can be applied. The results clarified that adopting the social responsibility perspective is possible. However, its application is not greatly done.

The research revealed that there are several obstacles related to the lack of BSC information, its application, and its importance in improving the performance. However, these obstacles do not significantly affect the application of BSC in the Egyptian travel agencies. The study recommends that the Egyptian Travel Agencies Association "ETAA" should intensify their efforts to spread the culture of the BSC approach among travel agencies in Egypt. Moreover, ETAA needs to provide intensive courses, seminars, and training programs to the staff to awareness of the BSC design and its use to monitor the performance. The top management in travel agencies needs to support the BSC system application and its development as well as it has to communicate the detailed information about the BSC implementation. It can propose to measure the relationships between managerial characteristics of travel agencies and performance measurement indicators used. Further research may focus on the effects of performance measurement practices on changing the BSC perspectives, measures, objectives, and initiatives in travel agencies

\section{References}

Agbanu, G., Nayrko, I.K., Agbemava, E., Sedzro, E., \& Selase, E. (2016). Measuring strategic performance in State -owned Organization: an evaluation of five proposed contemporary metrics. International Journal of Scientific and Research Publications, 6(1), 138- 153.

Agyeman, B., Bonn, J., \& Osei, C. (2017). Using Balanced Scorecard for Managing Performance in Selected Ghanaian Banks. International Journal of Business and Management, 12(12), 204.

Al-Najjar, S.M., \& Kalaf, K.H. (2012). Designing a balanced scorecard to measure a bank's performance: A case study. International journal of business administration, 3(4), 44.

Al-Zwyalif, I.M. (2012). The possibility of implementing balanced scorecard in Jordanian private universities. International Business Research, 5(11), 113.

Amado, C.A., Santos, S.P., \& Marques, P.M. (2012). Integrating the Data Envelopment Analysis and the Balanced Scorecard approaches for enhanced performance assessment. Omega, 40(3), 390-403.

Borza, A., \& Bordean, O. (2006). Performance measuring of tourism small medium-sized enterprises. Management \& Marketing, 1(4).

Cheng, M.I., Dainty, A., \& Moore, D. (2007). Implementing a new performance management system within a project-based organization. International Journal of Productivity and Performance Management.

Cooper, C., \& Hall, M. (2008). Contemporary Tourism An International Approach (1 st ed.). USA, Burlington,: Butterworth-Heinemann.

Curtis, P., Hanias, M., \& Antoniades, P. (2011). Balanced Scorecard as a strange attractor tool contributing to the improvement of transformation process and ultimately to the competitive advantage of an Organization. Journal of Engineering Science \& Technology Review, 4(3).

Edwards, S., \& Service, T.I. (2008). Balanced Scorecard Topic Gateway Series No. 2 (1st. ed.). United Kingdom, London: The Chartered Institute of Management Accountants "CIMA".

Elshahat, M.F. (2016). RESOURCE CONSUMPTION ACCOUNTING: THE CHALLENGES AND APPLICATION OBSTACLES. International Journal of Business, Accounting, \& Finance, 10(1).

Enz, C.A., Canina, L., \& Lomanno, M. (2010). Strategic pricing in european hotels: 2006-2009. Cornell Hospitality Report, 10(5), 4-22. 
Fawy, W.M., Mohammad, A.A., \& Dawood, A.A. (2018). A Proposed Empirical Model for Adopting Balanced Scorecard as a Tool for Performance Measurement in Hotels.

Fretheim, M. (2013). Developing a dynamic scorecard: a case study of a digital advertising firm. Norwegian University of Life Sciences.

Garg, A.K. (2013). BALANCED SCORECARD AND CORPORATE SOCIAL RESPONSIBILITY. International Journal of Management Research and Reviews, 3(7), 3178-3183.

Giannopoulos, G., Holt, A., Khansalar, E., \& Cleanthous, S. (2013). The use of the balanced scorecard in small companies. International Journal of Business and Management, 8(14), $1-22$.

Hsu, Y.-L., \& Liu, C.-C. (2010). Environmental performance evaluation and strategy management using balanced scorecard. Environmental Monitoring and Assessment, 170(1), 599-607. doi: 10.1007/s10661-009-1260-7

Ireland, R.D., Hoskisson, R., \& Hitt, M. (2008). Understanding business strategy: Concepts and cases: Nelson Education.

Kala, D., \& Bagri, S.C. (2014). Balanced scorecard usage and performance of hotels: A study from the tourist state of Uttarakhand, India. Asia-Pacific Journal of Innovation in Hospitality and Tourism (APJIHT), 3(2), 1-21.

Kang, J.-S., Chiang, C.-F., Huangthanapan, K., \& Downing, S. (2015). Corporate social responsibility and sustainability balanced scorecard: The case study of family-owned hotels. International Journal of Hospitality Management, 48, 124-134.

Kaplan, R.S. (2009). Conceptual foundations of the balanced scorecard. Handbooks of management accounting research, 3, 1253-1269.

Kaplan, R.S., \& Norton, D.P. (2004). Measuring the strategic readiness of intangible assets. Harvard Business Review, 82(2), 52-63.

Kasasbeh, I. (2018). Problems of Management Accounting Implementation: The Case of Balanced Scorecard Implementation within Jordanian Commercial Banks. International Journal of Academic Research in Accounting, Finance and Management Sciences, 8(2), 200-207.

Kerai, S., \& Saleh, A. (2017). Applying the Balanced Scorecard to Improve Student Satisfaction, Market Share and Profitability. AMR, 27.

Koumpouros, Y. (2013). Balanced scorecard: application in the general panarcadian hospital of tripolis, Greece. International journal of health care quality assurance.

Libby, T., Salterio, S.E., \& Webb, A. (2004). The balanced scorecard: The effects of assurance and process accountability on managerial judgment. The Accounting Review, 79(4), 10751094.

Lipe, M.G., \& Salterio, S.E. (2000). The balanced scorecard: Judgmental effects of common and unique performance measures. The Accounting Review, 75(3), 283-298.

Mooraj, S., Oyon, D., \& Hostettler, D. (1999). The balanced scorecard: a necessary good or an unnecessary evil? European Management Journal, 17(5), 481-491.

Mulat, M. (2015). Challenges of balanced scorecard measurement, cascading and evaluation the case of INSA. MSc Thesis, Addis Ababa University, Ethiopia, 11-16.

Niven, P. (2006). Balanced Scorecard Step-by-Step: Maximizing Performance and Maintaining Results (2 nd. ed.). USA, New Jersey: John Wiley \& Sons, Inc.

Niven, P. (2014). Balanced scorecard evolution: A dynamic approach to strategy execution: John Wiley \& Sons. 
Nurcahyo, R., Wibowo, A.D., \& Putra, R.F.E. (2015). Key performance indicators development for government agency. International Journal of Technology, 6(5), 856-863.

Phillips, P., \& Louvieris, P. (2005). Performance measurement systems in tourism, hospitality, and leisure small medium-sized enterprises: a balanced scorecard perspective. Journal of Travel Research, 44(2), 201-211.

Quesado, P., Aibar Guzmán, B., \& Lima Rodrigues, L. (2018). Advantages and contributions in the balanced scorecard implementation (Vol. 14).

Rasoolimanesh, S.M., Jaafar, M., Badarulzaman, N., \& Ramayah, T. (2015). Investigating a framework to facilitate the implementation of city development strategy using balanced scorecard. Habitat International, 46, 156-165.

Sahin, O. (2014). An investigation of student satisfaction factors. Journal of Research in Business and Managemet, 2(6), 8-1.

Schalm, C. (2008). Implementing a balanced scorecard as a strategic management tool in a longterm care organization: SAGE Publications Sage UK: London, England.

Valmohammadi, C., \& Servati, A. (2011). Performance measurement system implementation using Balanced Scorecard and statistical methods. International Journal of Productivity and Performance Management.

Van Staden, A. (2009). The Balanced Scorecard as performance measurement and personal development tool in a steel organisation. North-West University. 